\title{
Nonsteroidal Anti-inflammatory Drugs Modulate Gene Expression of Inflammatory Mediators in Oral Squamous Cell Carcinoma
}

\author{
DANIELLA MORAES ANTUNES ${ }^{1,2}$, MARIA FERNANDA SETÚBAL DESTRO RODRIGUES ${ }^{1,3}$, \\ DOUGLAS MAGNO GUIMARÃES ${ }^{1}$, CARINA MAGALHÃES ESTEVES DUARTE ${ }^{1}$, \\ LUCYENE MIGUITA $^{1}$, LUCIANA CORRÊA ${ }^{1}$, ANA PAULA LIGEIRO DE OLIVEIRA ${ }^{3}$, \\ KRISTIANNE PORTA SANTOS FERNANDES ${ }^{3}$ and FABIO DAUMAS NUNES ${ }^{1}$ \\ ${ }^{1}$ University of São Paulo, School of Dentistry, São Paulo, Brazil; \\ ${ }^{2}$ Faculty of Dentistry, Federal University of Mato Grosso do Sul, Mato Grosso do Sul, Brazil; \\ ${ }^{3}$ Biophotonics Applied to Health Science, Nove de Julho University, São Paulo, Brazil
}

\begin{abstract}
Background: Most patients with head and neck cancer receive nonsteroidal anti-inflammatory drugs concomitant with oncogenic treatment in order to control cardiovascular diseases and chronic inflammatory processes. Inflammation is closely related to neoplastic development and the release of inflammatory cytokines and chemokines represents a crucial event in this relationship. The aim of the present study was to evaluate the effect of acetylsalicylic acid (ASA) and celecoxib treatment in the gene expression pattern of cytokines and chemokines in squamous cell carcinoma (OSCC) cell lines. Materials and Methods: Cells were treated with plasmatic concentrations of ASA and celecoxib and were submitted to cell viability assay and immunoenzymatic assay to investigate interleukin 6 (IL6) production. Treated cells were collected and a gene expression array was performed using the reverse transcriptase-quantitative polymerase chain reaction. Results: Both treatments provoked a discrete inhibitory effect on cell viability and modulated IL6 production. The mRNA expression of several cytokines, chemokines, chemokine receptors, and other chemotaxis-related genes were modulated after treatment with ASA and celecoxib. Conclusion: Plasmatic doses of ASA and celecoxib altered the expression of IL6 and the gene expression of chemokines (ligands and receptors) and cytokines in a dose-and timedependent manner.
\end{abstract}

Correspondence to: Fabio Daumas Nunes, Av Professor Lineu Prestes 2227, Cidade Universitária, Butantã, Zip Code (CEP) 05508-000, São Paulo, Brazil. Tel: +55 1130917902, Fax: +55 1130917894, e-mail: fadnunes@usp.br

Key Words: Acetylsalicylic acid, celecoxib, oral squamous cell carcinoma, inflammation, cytokines, chemokines.
Cancer-related inflammation can be derived from extrinsic and intrinsic factors that determine the development and evolution of the tumor. On one hand, some etiological factors of cancer, such as viruses, bacteria and auto-immune diseases, can promote a chronic inflammatory response that induces malignant neoplastic transformation. On the other hand, intrinsic factors inherent to neoplastic cells, such as activated oncogenes and tumor-suppressor pathways, cause an inflammatory response, in which neoplastic cells release cytokines and growth factors. Independent of the origin of the inflammation, inflammatory status improves neoplastic cell surveillance by induction of proliferation and resistance (1).

Due to the marked role of inflammation in tumor aggressiveness, some anti-inflammatory drugs have been tested as targeted antineoplastic therapies. In head and neck cancer (HNC), cyclo-oxygenase (COX) inhibition by some nonsteroidal anti-inflammatory drugs (NSAIDs), such as ibuprofen, has been associated with a lower risk for cancer development and progression (2). Experimental studies have demonstrated that exposure to NSAIDs confers a protective effect against HNC (3) and inhibits the metastatic potential of head and neck squamous cell carcinoma (HNSCC) cells (4). However, there is no consensus as to whether NSAIDs, mainly acetylsalicylic acid (ASA) and celecoxib (CLX), reduce the risk of HNC (5-7).

Paying particular attention to oral squamous cell carcinoma (OSCC), some aspects of the role of inflammation on tumor progression have, indeed, been unraveled. It is known, for example, that the inflammatory cytokines interleukin 1 beta (IL1 $\beta)$, IL6, tumor necrosis factor (TNF $\alpha$ ) and the chemokines C-C motif chemokine ligand 5 (CCL5), C-X-C motif chemokine ligand 8 (CXCL8), CXCL10 play an important role in OSCC development and progression, as well as on radioresistance (8-10). However, the effect of NSAIDs on OSCC-related cytokines has been poorly addressed. 
Experimental studies with OSCC cell lines treated with ASA and CLX have focused on the effect of these drugs on adhesion molecules, cell migration and invasion (11), as well as on the inhibition of cell growth $(12,13)$. To date, as far as we are aware only one study has evaluated the effects of these NSAIDs on the modulation of inflammatory cytokines and growth factors in OSCC (8). The authors observed that after treatment with ASA $(2 \mathrm{mM})$, celecoxib $(25 \mu \mathrm{M})$ as well as other nuclear factor kappa B (NF-kB) inhibitors, a considerable decrease in IL6 and IL8 was observed, although no modulation of other cytokines was found.

In the present study, we aimed to evaluate the effect of ASA and CLX on the gene expression of cytokines and chemokines in OSCC cell lines.

\section{Materials and Methods}

Cell lines. OSCC cell lines (SCC4 and SCC9; American Type Culture Collection, Manassas, VA, USA) were grown in RPMI 1640 medium (Invitrogen, Carlsbad, CA, USA) supplemented with $10 \%$ fetal bovine serum (FBS; Invitrogen), 1\% L-glutamine and 1\% antifungal and antibiotic solution (Sigma-Aldrich St. Louis, MO, USA). The cells were maintained at $37^{\circ} \mathrm{C}$ in an atmosphere containing $5 \% \mathrm{CO}_{2}$ and $95 \%$ humidity until they reached $70-80 \%$ confluence.

Drug treatment. The cells were incubated for 1,6 and $12 \mathrm{~h}$ under concentrations of 1, 3 and $6 \mathrm{mM}$ for ASA (Aspirin; Sigma-Aldrich) and 1, 3 and $6 \mu \mathrm{M}$ for CLX (Pfizer, New York, NY USA). These concentrations were determined based on plasma concentrations in humans in which these drugs exert an anti-inflammatory effect (14).

ASA was prepared in ethanol and CLX in dimethyl sulfoxide (DMSO). The following experimental groups were set up: a) Control: cells incubated with normal medium; b) ethanol group: cells incubated with ethanol at the same concentrations used in the ASA group (0.1, 0.3 and $0.6 \%)$; c) ASA group: cells treated with ASA at concentrations of 1,3 and $6 \mathrm{mM}$ for 1,6 and $12 \mathrm{~h}$; d) DMSO group: cells incubated with DMSO at the same volume used in the CLX group (0.1, 0.3 and $0.6 \%)$; e) CLX group: cells treated with CLX at 1,3 and $6 \mu \mathrm{M}$ for 1,6 and $12 \mathrm{~h}$.

Immunoenzymatic assay (Luminex ${ }^{\circledR} x M A P^{T M}$ system). Bio-Plex ProTM Human Cytokine 17-plex Assay (Bio- Rad GmbH, Munich, Germany) was used for the analysis of the inflammatory cytokines produced by the SCC4 and SCC9 cell lines in the Control group. Supernatant was obtained from the cell cultures and measured according to the manufacturer's instructions using a Bio-Plex Pro II wash station and Bio-Plex Array Reader (Bio-Rad). Data was calculated by the Bio-Plex Manager software.

Cell viability assay. Cell viability was performed in quadruplicate using 3-(4,5-dimethylthiazol-2-yl)-2,5-diphenyltetrazolium bromide (MTT) (CellTiter 96 ${ }^{\circledR}$ AQueous One Solution Cell Proliferation Assay; Promega, Madison, WI, USA) for SCC4 and SCC9 cell lines in all groups. In a 96 -well plate, $5 \times 10^{3}$ cells were serum-free cultivated for $24 \mathrm{~h}$. After this period, RPMI $+10 \%$ FBS medium was added and cells were cultivated for an additional $12 \mathrm{~h}$. After treatment with ASA and CLX, the MTT $(5 \mu \mathrm{g} / \mathrm{ml})$ was added and after $2 \mathrm{~h}$ of incubation, the absorbance at $490 \mathrm{~nm}$ was determined at
1, 6, 12 and 24 hours using a spectrophotometer (ELX 800; BioTek Instruments Inc, Winooski, VT, USA). Three independent experiments were performed for both cell lines.

Immunoenzymatic assay for IL6. In the analysis of the cytokine profile for both OSCC cell lines, the highest values were found for IL6 and IL8 (see Results). It was previously reported that CLX has a modulatory effect only on IL6, not altering the IL8 concentration in inflammatory diseases $(15,16)$. Therefore, the effect of ASA and CLX on IL6 released by SCC4 and SCC9 cells was verified. To do this, we used a human IL6 ELISA kit Novex $^{\text {TM }}$; Invitrogen, Carlsbad, CA, USA). Three independent experiments using the treatments described above were performed in quadruplicate according to manufacturer's recommendations.

RNA extraction, cDNA synthesis and polymerase chain reaction $(P C R)$ array and RT-qPCR. RNA was extracted using (Thermo Fisher, Carlsbad, CA, USA) according to the manufacturer's instructions. The concentration and purity of the RNA were determined in a spectrophotometer (NANODROP 2000; Thermo Fisher Scientific, Waltham, MA, USA). For cDNA synthesis, $1 \mu \mathrm{g}$ of total RNA was reverse transcribed using RT2 First Strand Kit (Qiagen, Hilden, Germany). For gene expression analysis, the RT2 Profiler PCR Array system PAHS-022ZA (Qiagen) was used with 96-well plates containing primers for 84 genes (39 chemokine ligands, 36 chemokine receptors, 13 cytokines involved in chemotaxis, five cytokine receptors involved in chemotaxis and four other genes involved in chemotaxis), as well as five different endogenous control genes, a control for genomic DNA contamination, control of reverse transcriptase and positive control of the PCR reaction, according to the manufacturer's instructions. Reactions were performed using the 7,500 Real-Time PCR System (Applied Biosystems, Carlsbad, CA, USA) and the cycling conditions were: $10 \mathrm{~min}$ at $95^{\circ} \mathrm{C},\left(95^{\circ} \mathrm{C}\right.$ for $15 \mathrm{~s}, 60^{\circ} \mathrm{C}$ for $\left.60 \mathrm{~s}\right)(40$ cycles), followed by dissociation curve analysis.

The analysis of the differential expression genes was performed using RT2 Profiler PCR Array Data Analysis version 3.5, provided by the manufacturer through the website www.SABiosciences.com/ pcrarraydataanalysis.php. Normalization was achieved using the best endogenous gene selected by the software. This software classifies the average threshold cycle of the gene as follows: A: relatively high $(>30)$ in either the control or the test sample; B: relatively high $(>30)$, meaning that its relative expression level is low in both the control and test samples, and the p-value is either unavailable or relatively high $(>0.05)$; $\mathrm{C}$ : either not determined or greater than the defined cut-off value (default 35); and 'OKAY' (significant difference in gene expression between the samples). Only genes classified as 'A' or 'OKAY' by the software and with a fold change of $\geq 2$ or $\leq-2$ were considered as being differentially expressed.

RT-qPCR was performed on an ABI 7500 real-time PCR system (Applied Biosystems) using SYBR ${ }^{\circledR}$-Green mix (Applied Biosystems) and primers for the target genes $C-X-C$-Motif chemokine ligand 6 (CXCLO) (F: 5' agagctgcgttgcacttgtt 3'; R: 5' gcagtttaccaatcgtttgggg 3'), CKLF-like MARVEL transmembrane domain containing 4 (CMTM4) (F: 5' ttcaatcgtactggctgcttt 3'; R: 5' ccaggaatgtgttcactgcata 3'), C-C motif chemokine ligand 28 (CCL28) (F: 5' tgcacgga ggtttcacatcat 3', R: 5' ttggcagcttgcactttcatc 3') and platelet factor 4 variant 1 (PF4V1) F:5'agaaccccagcccgactttccc; R: 5'aacgccaagaac agcatctc 3') and for the constitutive gene glyceraldehyde-3-phosphate 


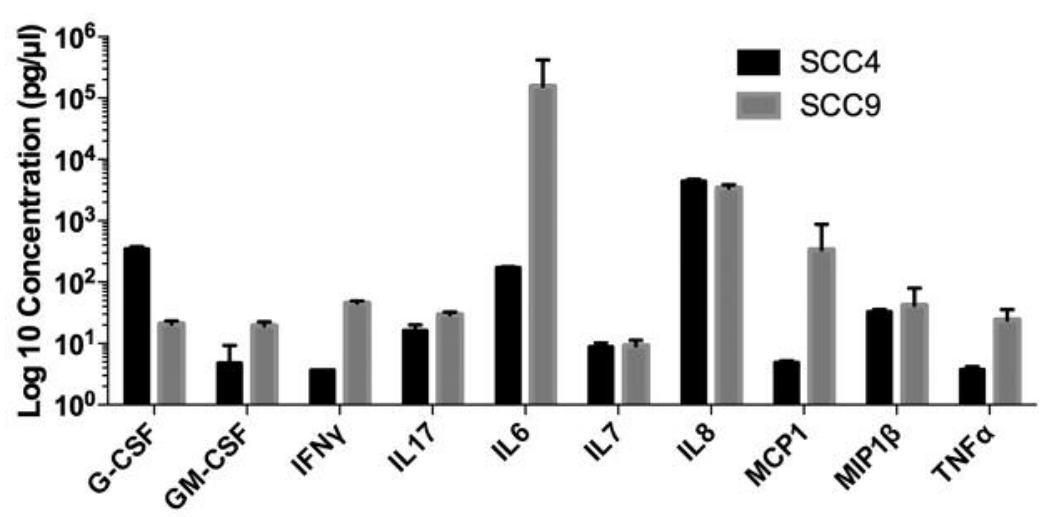

Figure 1. Concentration of cytokines and chemokines in SCC4 and SCC9 oral squamous cell carcinoma (OSCC) cell lines by the Bio-Plex Cytokine Assay. Both cell lines showed high levels of interleukin 6 (IL6) and IL8 protein production. G-CSF: Granulocyte colony-stimulating factor, GM-CSF: granulocyte-macrophage colony-stimulating factor, IFN $\gamma$ : interferon gamma, L17: interleukin 17, MCP1: monocyte chemoattractant protein-1, CCL4: C-C motif chemokine ligand 4, TNF $\alpha$ : tumor necrosis factor.

dehydrogenase $(G A P D H)$ (F: 5' gcatcctgggctacactga 3'; R: 5 'ccaccaccetgttgctgta $3^{\prime}$ '), which was used for normalization of the target gene. The qPCR cycling conditions were as follows: $95^{\circ} \mathrm{C}$ for $10 \mathrm{~min},\left(95^{\circ} \mathrm{C}\right.$ for $15 \mathrm{~s}, 60^{\circ} \mathrm{C}$ for $\left.60 \mathrm{~s}\right)$ (40 cycles) followed by dissociation curve analysis. Gene expression was calculated according to the Pfaffl mathematical model (17).

\section{Results}

OSCC cell lines express different cytokine profiles. This assay was performed to investigate the profile of cytokines, granulocyte colony-stimulating factor (G-CSF), GM-CSF, IFN $\gamma$, IL1 $\beta$, IL2, IL4, IL5, IL6, IL7, IL8, IL10, IL12 (p70), IL13, IL17, and TNF $\alpha$ ) and chemokines [monocyte chemoattractant protein-1 (MCP1) and C-C motif chemokine ligand 4 (CCL4)] produced by the SCC4 and SCC9 cell lines in the control group. Figure 1 shows the top 10 inflammatory mediators whose concentrations were higher than $10 \mathrm{pg} / \mu \mathrm{l}$. SCC4 cells presented a higher production of G-CSF in relation to SCC9 cells. On the other hand, SCC9 presented high levels of GM-CSF, IFN $\gamma$, IL2, IL6, MCP1 and TNF $\alpha$ when compared to SCC4. IL6 was expressed at the highest levels, being produced mainly by SCC9 cells. IL8 was also expressed at high levels for both cell lines.

NSAIDs provoked a discrete inhibitory effect on cell viability. After 1, 6 and $12 \mathrm{~h}$, no difference was observed between SCC4 and SCC9 cells treated with ethanol and with ASA at concentrations of 1, 3 and $6 \mathrm{mM}$ (Figure 2). In addition, both cell lines treated with CLX at 1, 3 and $6 \mu \mathrm{M}$ showed no difference in cellular viability in relation to cells treated with DMSO after 1 and $6 \mathrm{~h}$ (Figure 3). However, after $12 \mathrm{~h}$ of treatment, cellular viability of the SCC9 cell line treated with CLX at $6 \mu \mathrm{M}$ significantly decreased when compared to those treated with DMSO at the same concentration $(p=0.005)$ and when compared to SCC9 cells treated with CLX at $3 \mu \mathrm{M}(p=0.02)$ (Figure 3 ).

ASA and CLX at plasmatic concentrations modulate IL6 production. As shown in Figure 4A, there was no significant inhibitory effect on IL6 after 1 hour of exposure to ASA for any of the concentrations used. However, a significant increase in IL6 secretion was observed with ASA at $6 \mathrm{mM}$ when compared do vehicle control $(p=0.0078)$ after $6 \mathrm{~h}$ (Figure 4A). Twelve-hour treatment with ASA at $3 \mathrm{mM}$ and $6 \mathrm{mM}$ was associated with a significant decrease in IL6 when compared to their respective vehicle control $(p=0.0002$ and $p=0.03$, respectively) and with ASA at $1 \mathrm{mM}(p<0.001)$ (Figure 4A). There were no significant differences between the effect of $3 \mathrm{mM}$ and $6 \mathrm{mM}$ for any of the exposure times.

In relation to CLX, no significant differences were observed after 1 and $12 \mathrm{~h}$ with CLX at 1, 3 and $6 \mu \mathrm{M}$ (Figure 4B). After $6 \mathrm{~h}$, treatment with CLX at $6 \mu \mathrm{M}$ was associated with a significant increase in IL6 $(p=0.008)$ in relation to CLX at 3 $\mu \mathrm{M}$ (Figure 4B). No modulation of IL6 was observed in SCC4 cell line treated with different concentrations of ASA or CLX after 1,6 and $12 \mathrm{~h}(p>0.05)$ (data not shown).

Looking at the extent of inhibitory or stimulatory effects of the drugs, we noticed that the ASA at $3 \mathrm{mM}$ for $12 \mathrm{~h}$ (IL6 mean of $267.68 \pm 3.73 \mathrm{pg} / \mathrm{ml}$ ) and CLX at $6 \mu \mathrm{M}$ for $6 \mathrm{~h}$ (IL6 mean of $365.19 \pm 39.79 \mathrm{pg} / \mathrm{ml}$ ) exerted the most marked inhibitory and stimulatory effects on IL6, respectively. Therefore, these concentrations and time incubations were chosen for evaluating gene expression in the subsequent assay.

SCC4 and SCC9 cells showed different chemokine and cytokine gene modulations after treatment with NSAIDs. The up-regulated and down-regulated genes observed in SCC4 and SCC9 cell lines after treatment with ASA and CLX, as 
$1 \mathrm{~h}$
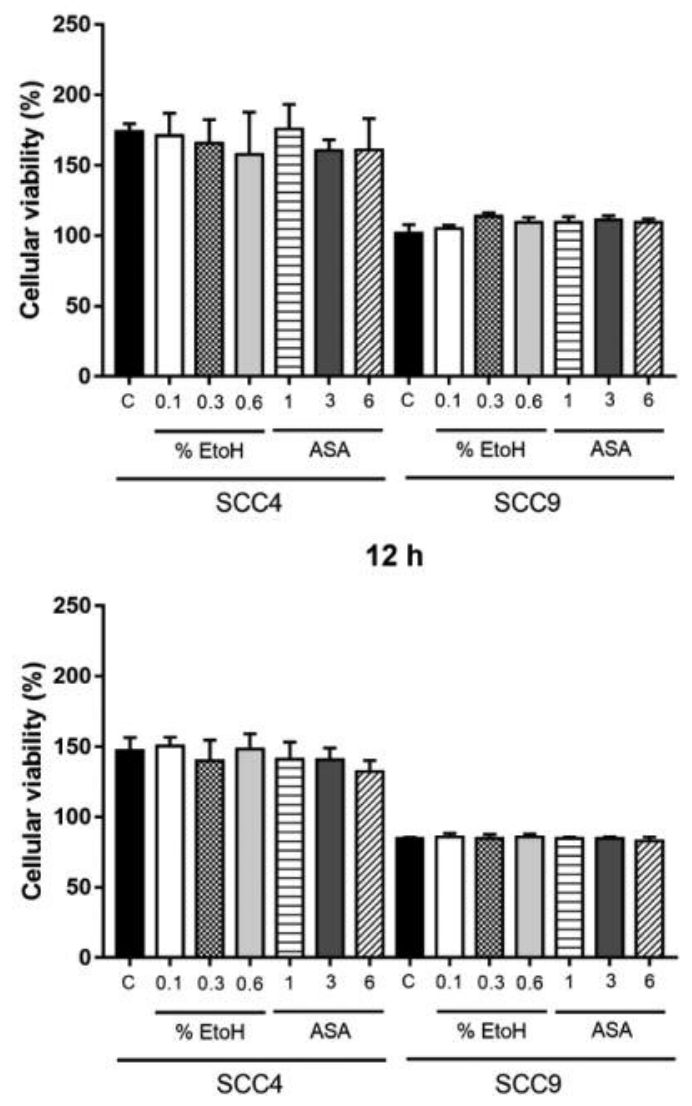

well as the fold-change values are described in Tables I and II. In SCC4 cells, ASA treatment reduced the expression of atypical chemokine receptor 4 (ACKR4), CXCL10, CXCL11, CXCL3, CXCL6, CXCL8 and PF4V1 genes, and increased the expression of $\mathrm{G}$ protein-coupled receptor 17 (GPR17). In SCC9 cells, ASA increased the expression of CCL17, CCL20, CCL28, CCL3, CCL4, CCR10, CXCR2, CMTM4, IL1B and IL16. In SCC4 cells, CLX reduced the expression of ACKR3, CXCL6 and PF4V1. In SCC9 cells, there was an increase in the expression of CCL28, CMTM1, CMTM3, CMTM4, CXCR6, slit guidance ligand 2 (SLIT2), toll-like receptor 2 (TLR2), TLR4, TNF $\alpha$ and thymidine phosphorylase (TYMP). Globally, ASA and CLX tended to up-regulate the chemokine and cytokine genes in SCC9 cells and to down-regulate genes in $\mathrm{SCC} 4$ cells.

To confirm the results obtained by PCR array, we selected CMTM4 and CCL28 genes overexpressed in SCC9 cells and CXCL6 and PF4V1 genes down-regulated in SCC4 cells for validation by RT-qPCR of the differential gene expression observed after treatment with ASA and CLX by the PCR array. As demonstrated in Figure 5, CMTM4 was up-regulated in SCC9 treated with CLX (fold-change 4.45, $p=0.0052$ ) and $C C L 28$ gene was overexpressed after treatment with ASA
$6 \mathrm{~h}$

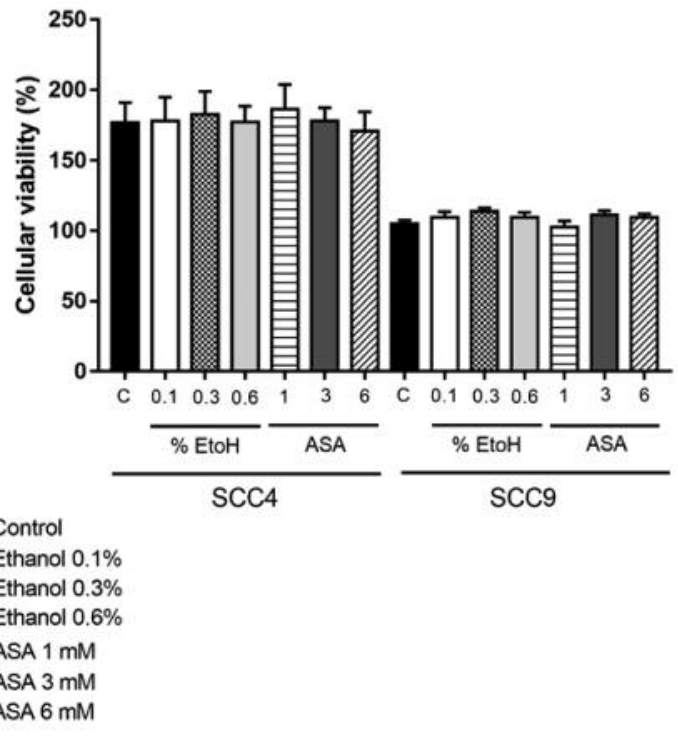

Figure 2. Cellular viability of SCC4 and SCC9 oral squamous cell carcinoma cell lines (OSCC) treated with ethanol (vehicle control) and acetylsalicylic acid (ASA) at 1,3 and $6 \mathrm{mM}$ for 1, 6 and $12 \mathrm{~h}$. Data are the mean ( \pm standard deviation).

(fold-change 7.67, $p=0.03$ ) and CLX (fold-change 3.23, $p=0.07$ ) when compared to control (Figure 5A and B). SCC4 cell line showed lower expression level of CXCL6 after treatment with both ASA (fold-change: $-10.25, p=002$ ) and CLX (fold-change: $-4.59, p=0.05$ ) (Figure 5C). In addition, a significant decrease in the mRNA expression level of PF4V1 was also observed after ASA (fold-change: -7.77 , $p=0.01$ ) and CLX (fold-change: $-4.59, p=0.03$ ) treatments in relation to the control (Figure 5D).

\section{Discussion}

To our knowledge, this is the first study to perform a screening of chemokine ligands, chemokine receptors, cytokines and cytokine receptors involved in OSCC, after treatment with ASA and CLX. The present work showed that ASA and CLX, used in concentrations near plasmatic levels in humans, were able to modulate the mRNA expression of several inflammatory proteins in two OSCC cell lines. We found important differences between the effects of ASA compared to CLX on inflammatory protein expression, as well as between SCC4 and SCC9 cells, as we discuss below. 
$1 \mathrm{~h}$
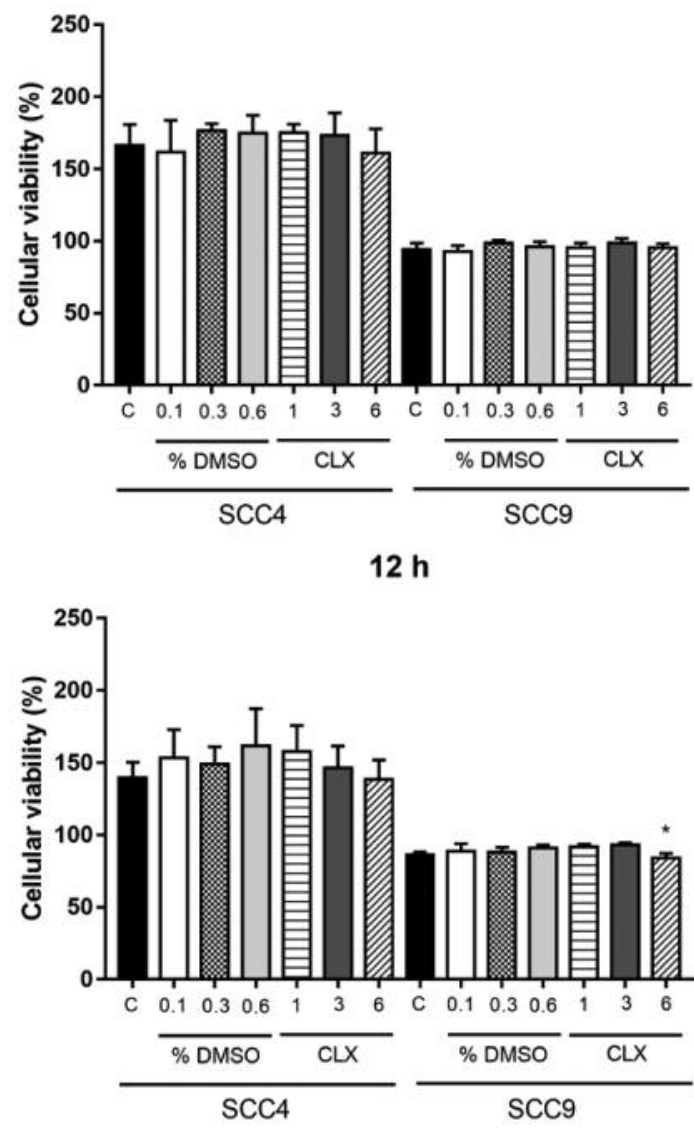

$6 \mathrm{~h}$

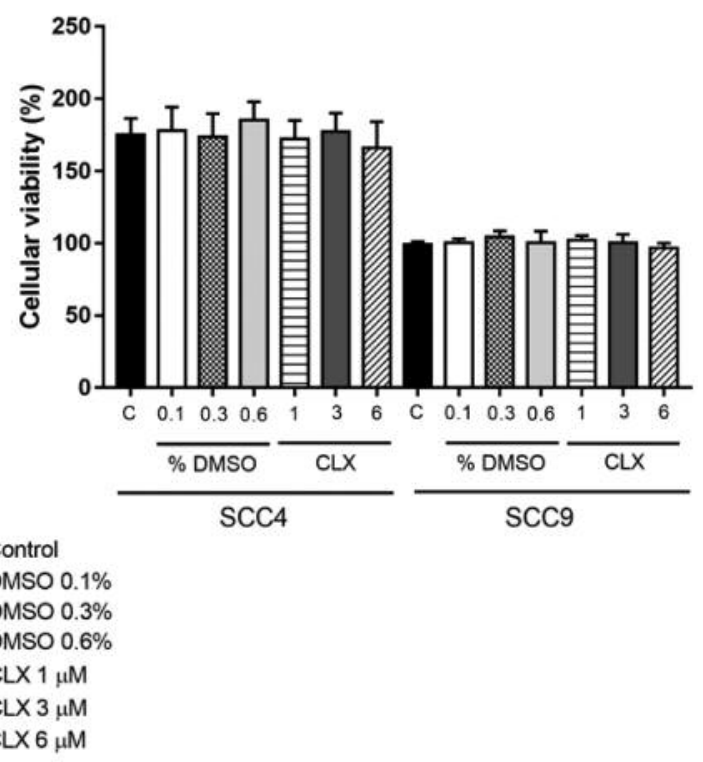

Figure 3. Cellular viability of SCC4 and SCC9 oral squamous cell carcinoma (OSCC) cell lines treated with dimethyl sulfoxide (vehicle control) and celecoxib $(C L X)$ at 1, 3 and $6 \mu M$ for 1, 6 and $12 \mathrm{~h}$. Data are the mean ( \pm standard deviation). *Significantly different from dimethyl sulfoxide (DMSO) at $0.6 \%(p=0.005)$ and CLX at $3 \mu M(p=0.02)$, Tukey's test.

Firstly, we analyzed the cytokine panel released by OSCC cell lines without any treatment. For example, we found that IL6 was produced at high levels by SCC9 cells, but at moderate levels by SCC 4 cells. In OSCC, the high expression of IL6 is related to worse prognosis $(18,19)$, and increased invasion, metastasis, and chemoresistance $(20,21)$. The two cell lines used in the present study were chosen for their ability to simulate the various OSCC phenotypes; which probably influenced the results (22).

Although the two cell lines expressed the cytokines differently, there were no important differences in relation to cell viability after NSAID treatments. In general, the drugs did not drastically inhibit cell growth of either cell line, even after 12-h exposure. Another study also demonstrated that ASA did not inhibit OSCC cell growth at concentrations up to $30 \mathrm{mM}$ for 6 days of exposure (13), differing from another investigation in which ASA reduced OSCC cell growth at $2 \mathrm{mM}$ after $72 \mathrm{~h}$ (8). CLX showed a higher potency for cell growth inhibition compared to other NSAIDs, with concentrations ranging from 10 to $50 \mu \mathrm{M}$ (13), and an exposure time of $72 \mathrm{~h} \mathrm{(8,}$ $23)$. We probably did not observe any notable cell growth

inhibition due to the use of low drug concentrations and reduced exposure times.

The potential of cytokine inhibition by COX inhibitors was evident mainly after $12 \mathrm{~h}$ of drug exposure. We detected that the inhibitory effect of ASA on IL6 increased in accordance with the exposure time and concentration, but this tendency was not observed for CLX. On the contrary, some CLX concentrations improved IL6 production, mainly after 1 and $6 \mathrm{~h}$. This fact was not reported in the study performed by Meyer et al. (8), but the concentrations and exposure times were higher than those used in the present study. Regarding the opposite effect of CLX at concentrations of 3 and $6 \mu \mathrm{M}$ on IL6 production, we believe that it may be related to the loss of the anti-inflammatory effect of the drug when used at higher doses, as reported by Niederberger et al. (24). Interestingly, in the study by Zhao et al., in patients with osteoarthritis who were treated with several doses of CLX, a dose of $100 \mathrm{mg}$ led to better control of inflammatory symptoms than did a dose of 200 or $500 \mathrm{mg}$ (25).

Although the CLX administration period is every $12 \mathrm{~h}$ (25), no significant effect on IL6 cytokine production after $12 \mathrm{~h}$ of treatment was observed in this study. Gallelli et al. reported a drastic reduction of IL6 in synovial fluid in patients who 


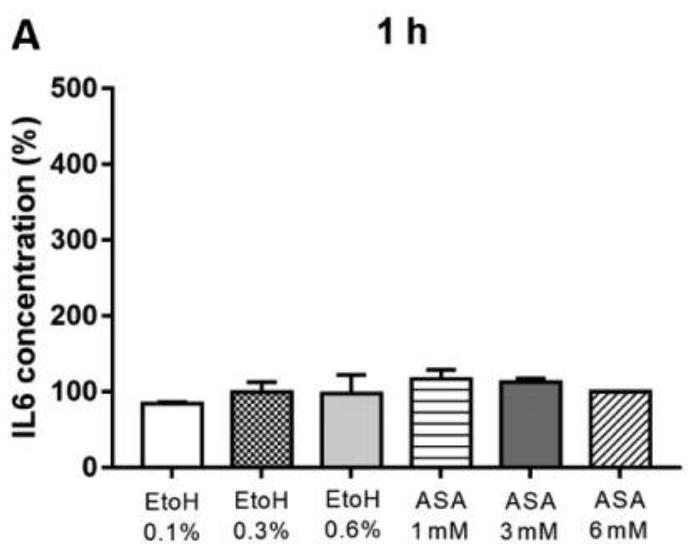

$6 \mathrm{~h}$

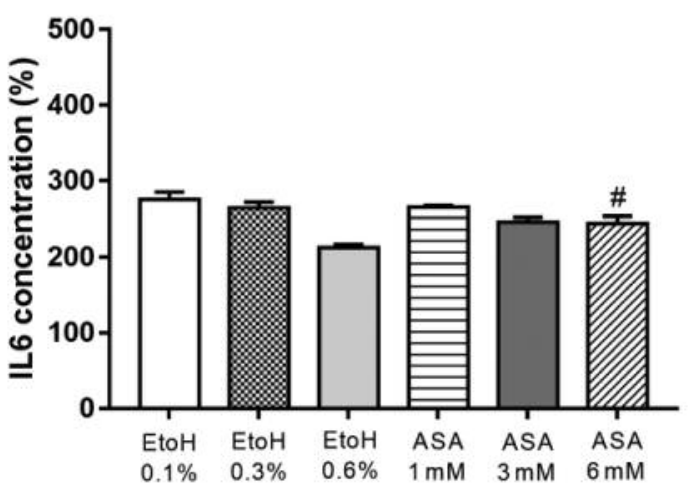

$12 \mathrm{~h}$

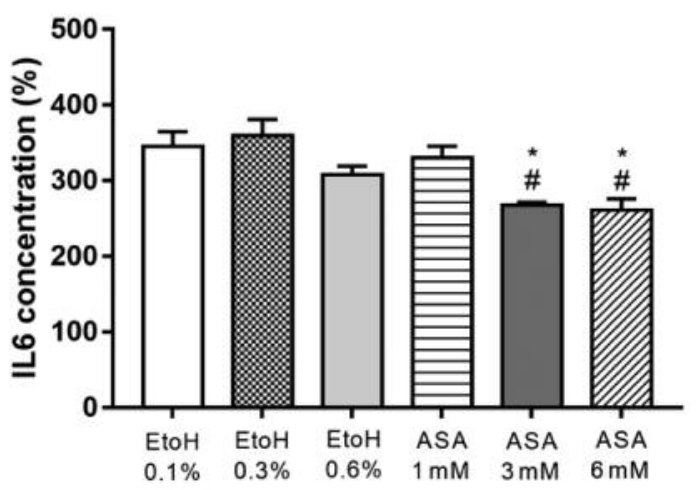

B $1 \mathrm{~h}$

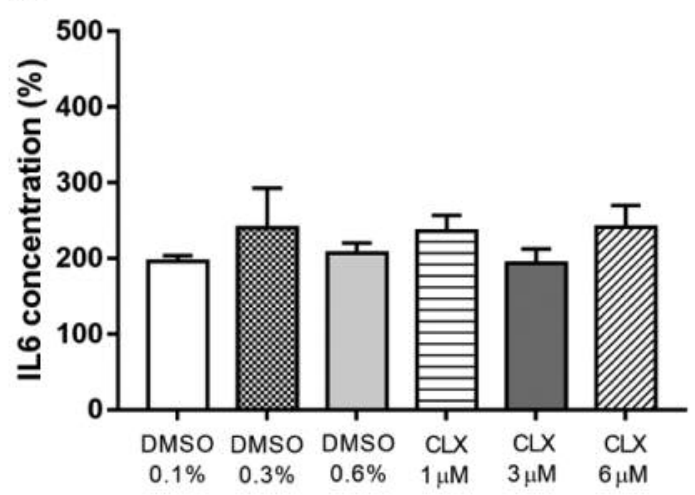

$6 \mathrm{~h}$

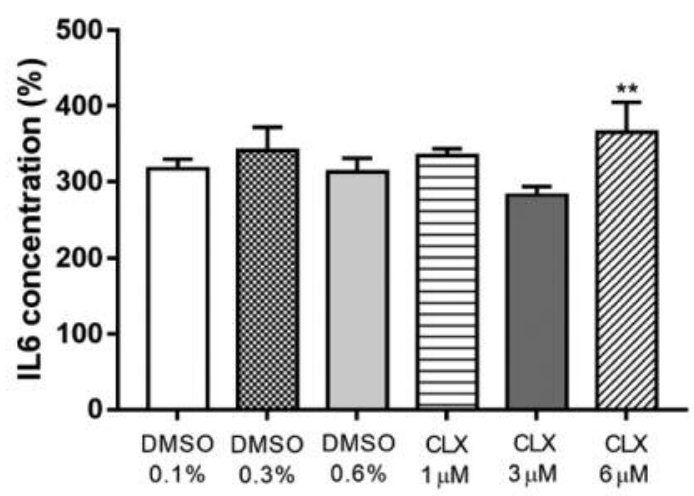

$12 \mathrm{~h}$

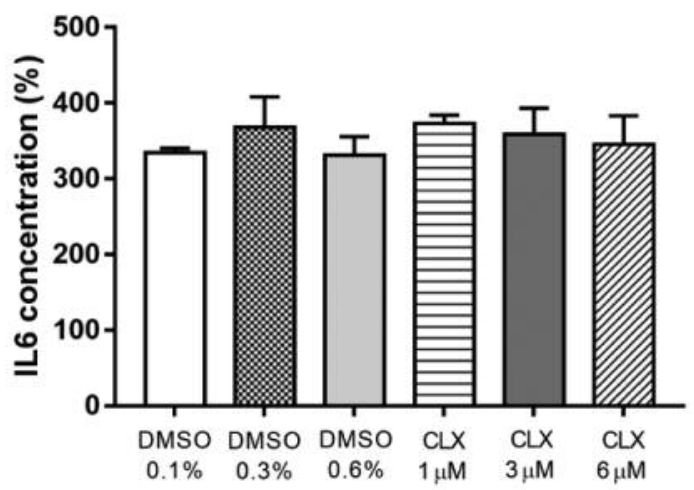

Figure 4. Interleukin 6 (IL6) concentration released by SCC9 oral squamous cell carcinoma (OSCC) cells after treatment with acetylsalicylic acid (ASA) (A) and celecoxib (CLX) (B) after 1, 6 and $12 \mathrm{~h}$. Data are the mean \pm standard-deviation. Significantly different from " ${ }^{\#}$ corresponding ethanol control ( $p=0.0078,0.0002$ and $p=0.03 ; * A S A$ at $1 \mathrm{mM}(p<0.001)$ and $* * C L X$ at $3 \mu M(p=0.008)$, Tukey's test.

received CLX every $12 \mathrm{~h}$ (16). Intriguingly, in a clinical study conducted in 2008, the use of oral CLX every $12 \mathrm{~h}$ for 12 weeks reduced the severity of epithelial dysplasia in patients with oral premalignant lesions (26). Recent clinical studies used CLX every $12 \mathrm{~h}$ in metronomic chemotherapy regimens and achieved satisfactory results in increasing tumor progressionfree survival in patients with HNC (27).
We also performed a gene expression screening of inflammatory cytokines and their receptors, after treatment of cells with ASA and CLX. In general, the SCC9 cell line exhibited up-regulation of genes and SCC4 cells showed down-regulation. We noted that chemokines, mainly $\mathrm{CCs}$ (CCL3, -4, -17, -20, and -28) and CXCs (CXCL3, -6, -8, -10, -11 , and -16 ), were particularly modulated by NSAIDs, mainly 
Table I. Genes differentially expressed in SCC4 and SCC9 cell lines treated with acetylsalicylic acid (ASA) relative to the control group.

\begin{tabular}{lccc}
\hline Cell line & Gene & Description & Fold-change \\
\hline SCC4 & GPR17 & G Protein-coupled receptor 17 & 8.16 \\
& PF4V1 & Platelet factor 4 variant 1 & -3.53 \\
& CXCL10 & C-X-C motif chemokine ligand 10 & -2.46 \\
& ACKR4 & Atypical chemokine receptor 4 & -2.41 \\
CXCL8 & C-X-C motif chemokine ligand 8 & -2.41 \\
& CXCL3 & C-X-C motif chemokine ligand 3 & -2.22 \\
CXCL11 & C-X-C motif chemokine ligand 11 & -2.13 \\
CXCL6 & C-X-C motif chemokine ligand 6 & -2.08 \\
IL1B & Interleukin 1 beta & 13.30 \\
CXCR2 & C-X-C motif chemokine receptor 2 & 7.07 \\
CCC54 & C-C motif chemokine ligand 4 & 5.93 \\
CCL20 & C-C motif chemokine ligand 20 & 5.01 \\
CCL3 & C-C motif chemokine ligand 3 & 4.61 \\
CCL28 & C-C motif chemokine ligand 28 & 4.13 \\
CCL17 & C-C motif chemokine ligand 17 & 3.82 \\
CCR10 & C-C motif chemokine receptor 10 & 3.75 \\
CMTM4 & CKLF-like MARVEL transmembrane & 3.23 \\
& domain-containing 4 & \\
IL16 & Interleukin 16 & 3.06 \\
\hline
\end{tabular}

Table II. Genes differentially expressed in SCC4 and SCC9 cell lines treated with Celecoxib $(C L X)$ relative to the control group.

\begin{tabular}{cccc}
\hline Cell line & Gene & Description & Fold-change \\
\hline SCC4 & PF4V1 & Platelet factor 4 variant 1 & -3.40 \\
& ACKR3 & Atypical chemokine receptor 3 & -2.15 \\
& CXCL6 & C-X-C motif chemokine ligand 6 & -2.03 \\
SCC9 & CMTM3 & CKLF like MARVEL transmembrane \\
& \multicolumn{4}{c}{ domain containing 3 } & 38.04 \\
& TYMP & Thymidine phosphorylase & 25.25 \\
CXCR6 & C-X-C motif chemokine receptor 6 & 8.77 \\
TNFa & Tumor necrosis factor & 8.01 \\
TLR4 & Toll-like receptor 4 & 6.31 \\
CMTM1 & CKLF like MARVEL transmembrane & 5.78 \\
& \multicolumn{4}{c}{ domain containing 1 } \\
CMTM4 & CKLF like MARVEL transmembrane & 4.18 \\
& \multicolumn{4}{c}{ domain containing 4 } \\
CCL28 & C-C motif chemokine ligand 28 & 3.92 \\
SLIT2 & Slit guidance ligand 2 & 3.82 \\
TLR2 & Toll-like receptor 4 & 3.37 \\
\hline
\end{tabular}

by ASA. In vitro and in vivo studies have found an association between CCL2, -3, -7 and -20 expression with OSCC invasion, migration and lymph node metastasis (28-31). Of the CXC family, the members most studied in OSCC are CXCL8 and CXCL12, whose expression has been related to increased cell proliferation, angiogenesis, invasion, migration and metastasis $(9,32,33)$. Interestingly, in response to ASA treatment, the
SCC4 cell line showed a decreased expression of the CXCL chemokines (CXCL3, -6, -8, -10, and -11) and the SCC9 cell line showed increased expression in the CC family (CCL3, -4 , $-17,-20$, and -28). Chemokine receptor genes were also modulated in the SCC9 line by the treatments performed in the present study. Treatment with ASA increased the expression of CXCR2 and CCR10 and with CLX the expression of CXCR6 was increased. The high affinity binding of CXCR1 and CXCR2 to chemokine CXCL8 in OSCC cell lines showed an important effect on increased proliferation, migration, invasion and production of metalloproteinases (34). Regular use of ASA reduced CCL15 and increased CCL13 and -17 in older patients with cancer (35), but the relationship of this modulation with tumor prognosis has not yet been established.

Regarding other inflammatory cytokines, ASA and CLX were associated with an increase in $I L I B$ and $T N F \alpha$ gene expression, respectively. Both cytokines are able to activate $\mathrm{NF}-\mathrm{kB}$, which is related to many pro-tumoral processes (36, 37). In HNC, elevated plasma levels of TNF $\alpha$ have been related to reduced survival of patients (38).

CLX also improved the gene expression of TLR2 and TLR4. Recently TLRs have been implicated in both antitumor and protumoral events of carcinogenesis (39). In OSSC, the expression of TRL2, -4 and -9 was found to be involved in the development and progression of this tumor type (40). The effect of CLX on TLRs is poorly understood in cancer, including OSCC. ASA and CLX reduced the expression of TLR3 in OSSC cells in another study (8).

The highest fold-change detected in the present study was for SCC9 cells treated with CLX, and involved the CMTM family (CKLF-like MARVEL transmembrane domain). CLX up-regulated the expression of CMTM3 by 38-fold; in addition, CMTM1 and -4 were also up-regulated by CLX and ASA, but at a lower intensity. There are few studies addressing the role of these proteins in cancer. In OSCC, Zhang et al. (41) associated the expression of CMTM3 and CMTM5 with OSSC prognosis.

Atypical chemokine receptors (ACRs), more specifically $A C K R 3$ and $A C K R 4$ genes, were down-regulated in the SCC4 cell line after CLX and ASA treatment, respectively. The most common ACKR4 ligands are CCL19, CCL21, CCL25 and CXCL13 (42, 43). Increased expression of this receptor has been implicated as a negative regulator of tumor growth and metastasis $(44,45)$. However, this gene has never been previously investigated in OSCC, and the effect of NSAIDs on these receptors is unknown.

Finally, we observed a decrease in PF4VI gene expression by SCC4 cells treated with both ASA and CLX. The chemokine PF4V1 plays an important homeostatic role under physiological and pathological conditions (46). In a recent study, Jian et al. found a positive correlation between the expression of PF4VI and the survival of patients with lung cancer (47). Although several studies 
A

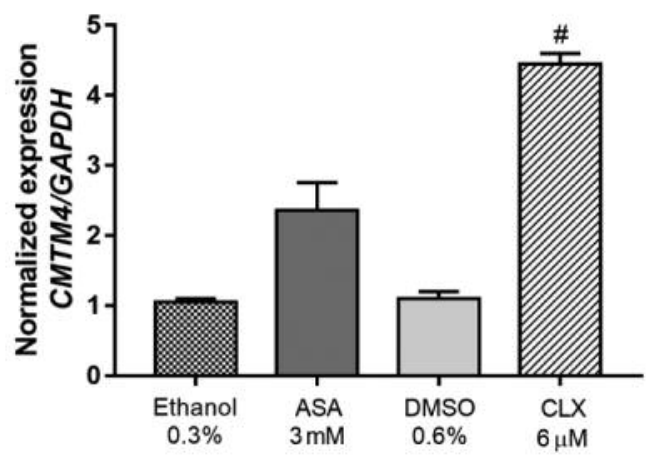

C

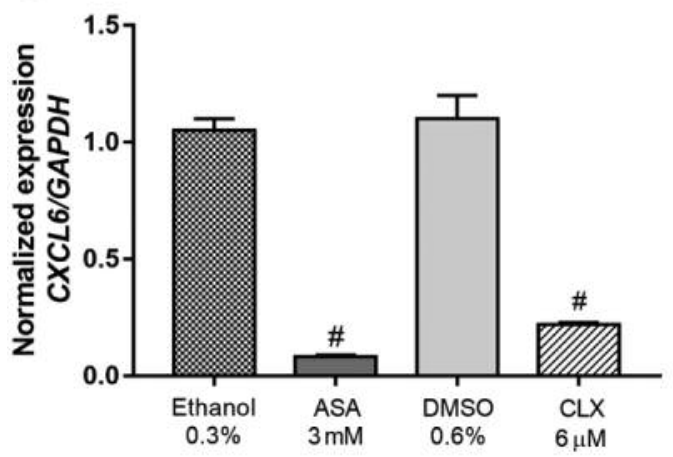

B

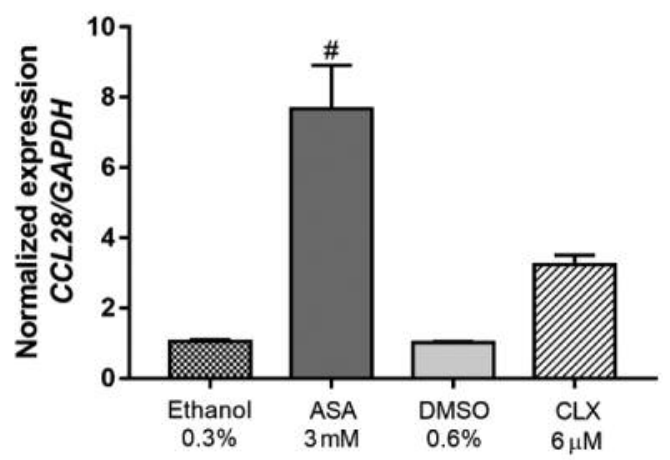

D

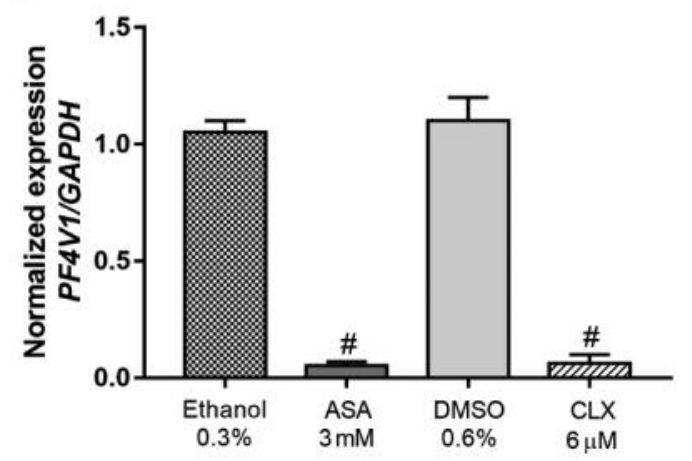

Figure 5. Evaluation of the overexpressed genes CKLF-like MARVEL transmembrane domain-containing 4 (CMTM4) (A) and C-C motif chemokine ligand 28 (CCL28) (B) in SCC9 and the down-regulated genes $C-X-C$ and platelet factor 4 variant 1 (CXCL6) (C) and platelet factor 4 variant 1 $(P F 4 V 1)(D)$ in SCC4 by reverse transcriptase-quantitative polymerase chain reaction (RT-qPCR) after treatment with acetylsalicylic acid (ASA) and celecoxib $(C L X)$. Three independent experiments were performed. Glyceraldehyde-3-phosphate dehydrogenase (GAPDH). "Significantly different from the vehicle control at $p<0.05$, unpaired t-test with Welch's correction.

have shown that PF4VI is able to modulate tumor development (47), its role in OSCC is poorly understood.

In conclusion, plasmatic doses of ASA and CLX altered the expression of IL6 and the gene expression of chemokines (ligands and receptors), cytokines, and other protein-related inflammation molecules in OSCC cell lines in a dose- and time-dependent manner, with different patterns related to the type of OSCC cell line and drug concentration/exposure time. Further investigation is necessary to elucidate the mechanisms of action of NSAIDs on these proteins, especially in the context of patients with HNC.

\section{Funding}

This research did not receive any specific grant from funding agencies in the public, commercial, or not-for-profit sectors.

\section{Conflicts of Interest}

The Authors declare that there are no conflicts of interest in regard to this study.

\section{Authors' Contributions}

Daniella Moraes Antunes: carried out the literature research, experimental studies, data acquisition and its analysis, article preparation, editing and its review. Maria Fernanda Setúbal Destro Rodrigues carried out experimental studies, data acquisition and its analysis, article preparation, editing and its review. Douglas Magno Guimarães carried out experimental studies and data acquisition. Carina Magalhães Esteves Duarte carried out experimental studies and data acquisition. Lucyene Miguita: carried out experimental studies, data acquisition and its analysis. Luciana Corrêa participated in data acquisition and its analysis and critically reviewed the article. Ana Paula Ligeiro de Oliveira participated in data acquisition and its analysis. Kristianne Porta Santos Fernandes critically reviewed the article. Fabio Daumas Nunes conceived the study, participated in its design and coordination, carried out experimental studies, data acquisition and statistical analysis, article preparation, editing and its review.

\section{References}

1 Candido J and Hagemann T: Cancer-related inflammation. J Clin Immunol 33(Suppl 1): S79-84, 2013. PMID: 23225204. DOI: 10.1007/s 10875-012-9847-0 
2 Becker C, Wilson JC, Jick SS and Meier CR: Non-steroidal antiinflammatory drugs and the risk of head and neck cancer: A case-control analysis. Int J Cancer 137(10): 2424-2431, 2015. PMID 25974157. DOI: 10.1002/ijc.29601

3 Lee DW, Sung MW, Park SW, Seong WJ, Roh JL, Park B, Heo DS and Kim KH: Increased cyclooxygenase-2 expression in human squamous cell carcinomas of the head and neck and inhibition of proliferation by nonsteroidal anti-inflammatory drugs. Anticancer Res 22(4): 2089-2096, 2002. PMID: 12174888.

4 Fujii R, Imanishi Y, Shibata K, Sakai N, Sakamoto K, Shigetomi S, Habu N, Otsuka K, Sato Y, Watanabe Y, Ozawa H, Tomita T, Kameyama K, Fujii M and Ogawa K: Restoration of E-cadherin expression by selective Cox-2 inhibition and the clinical relevance of the epithelial-to-mesenchymal transition in head and neck squamous cell carcinoma. J Exp Clin Cancer Res 33: 40, 2014. PMID: 24887090. DOI: 10.1186/1756-9966-33-40

5 Kim SA, Roh JL, Kim SB, Choi SH, Nam SY and Kim SY: Aspirin use and head and neck cancer survival: An observational study of 11,623 person-years follow-up. Int J Clin Oncol 23(1): 5258, 2018. PMID: 28725937. DOI: 10.1007/s10147-017-1165-3

6 Shi J, Leng W, Zhao L, Xu C, Wang J, Chen X, Wang Y and Peng X: Nonsteroidal anti-inflammatory drugs using and risk of head and neck cancer: a dose-response meta analysis of prospective cohort studies. Oncotarget 8(58): 99066-99074, 2017. PMID: 29228752. DOI: 10.18632/oncotarget.21524

7 Tang L, Hu H, Liu H, Jian C, Wang H and Huang J: Association of nonsteroidal anti-inflammatory drugs and aspirin use and the risk of head and neck cancers: A meta-analysis of observational studies. Oncotarget 7(40): 65196-65207, 2016. PMID: 27533 449. DOI: $10.18632 /$ oncotarget.11239

8 Meyer C, Pries R and Wollenberg B: Established and novel NFkappaB inhibitors lead to downregulation of TLR3 and the proliferation and cytokine secretion in HNSCC. Oral Oncol 47(9): 818-826, 2011. PMID: 21745758. DOI: 10.1016/j.oraloncology. 2011.06.010

9 Rao SK, Pavicevic Z, Du Z, Kim JG, Fan M, Jiao Y, Rosebush M, Samant S, Gu W, Pfeffer LM and Nosrat CA: Proinflammatory genes as biomarkers and therapeutic targets in oral squamous cell carcinoma. J Biol Chem 285(42): 32512-32521, 2010. PMID: 20702412. DOI: 10.1074/jbc.M110.150490

10 Rentoft M, Coates PJ, Loljung L, Wilms T, Laurell G and Nylander K: Expression of CXCL10 is associated with response to radiotherapy and overall survival in squamous cell carcinoma of the tongue. Tumour Biol 35(5): 4191-4198, 2014. PMID: 24395654. DOI: $10.1007 / \mathrm{s} 13277-013-1549-6$

$11 \mathrm{Li} \mathrm{WZ}$, Huo QJ, Wang XY and Xu F: Inhibitive effect of celecoxib on the adhesion and invasion of human tongue squamous carcinoma cells to extracellular matrix via downregulation of MMP-2 expression. Prostaglandins Other Lipid Mediat 93(3-4): 113-119, 2010. PMID: 20709621. DOI: 10.1016/j.prostaglandins .2010 .08 .001

12 Park SW, Kim HS, Hah JW, Jeong WJ, Kim KH and Sung MW: Celecoxib inhibits cell proliferation through the activation of ERK and p38 MAPK in head and neck squamous cell carcinoma cell lines. Anticancer Drugs 21(9): 823-830, 2010. PMID: 20717005. DOI: $10.1097 / C A D .0 b 013 e 32833$ dada8

13 Yang CY, Meng CL, Liao CL and Wong PY: Regulation of cell growth by selective COX-2 inhibitors in oral carcinoma cell lines. Prostaglandins Other Lipid Mediat 72(3-4): 115-130, 2003. PMID: 14674624. DOI: 10.1016/S1098-8823(03)00053-4
14 Juarez Olguin H, Flores Perez J, Lares Asseff I, Loredo Abdala A and Carbajal Rodriguez L: Comparative pharmacokinetics of acetyl salicylic acid and its metabolites in children suffering from autoimmune diseases. Biopharm Drug Dispos 25(1): 1-7, 2004. PMID: 14716747. DOI: 10.1002/bdd.379

15 Bianchi M, Broggini M, Balzarini P, Franchi S and Sacerdote P: Effects of nimesulide on pain and on synovial fluid concentrations of substance $P$, interleukin- 6 and interleukin- 8 in patients with knee osteoarthritis: comparison with celecoxib. Int J Clin Pract 61(8): 1270-1277, 2007. PMID: 17590218. DOI: 10.1111/j.1742-1241.2007.01453.x

16 Gallelli L, Galasso O, Falcone D, Southworth S, Greco M, Ventura V, Romualdi P, Corigliano A, Terracciano R, Savino R, Gulletta E, Gasparini G and De Sarro G: The effects of nonsteroidal antiinflammatory drugs on clinical outcomes, synovial fluid cytokine concentration and signal transduction pathways in knee osteoarthritis. A randomized open label trial. Osteoarthritis Cartilage 21(9): 14001408, 2013. PMID: 23973155. DOI: 10.1016/j.joca.2013.06.026

17 Pfaffl MW: A new mathematical model for relative quantification in real-time RT-PCR. Nucleic Acids Res 29(9): e45, 2001. PMID: 11328886. DOI: 10.1093/nar/29.9.e45

18 Goda H, Okamoto M, Nakashiro KI, Hino S, Murase R and Hamakawa $\mathrm{H}$ : Prognostic impact of preoperative serum interleukin-6 levels in patients with early-stage oral squamous cell carcinoma, defined by sentinel node biopsy. Oncol Lett 14(6): 7965-7969, 2017. PMID: 29344239. DOI: 10.3892/ol.2017.7183

19 Shinagawa K, Yanamoto S, Naruse T, Kawakita A, Morishita K, Sakamoto Y, Rokutanda S and Umeda M: Clinical roles of interleukin-6 and STAT3 in oral squamous cell carcinoma. Pathol Oncol Res 23(2): 425-431, 2017. PMID: 27744625. DOI: 10.1007/s12253-016-0134-x

20 Gao J, Zhao S and Halstensen TS: Increased interleukin-6 expression is associated with poor prognosis and acquired cisplatin resistance in head and neck squamous cell carcinoma. Oncol Rep 35(6): 32653274, 2016. PMID: 27108527. DOI: 10.3892/or.2016.4765

21 Jinno T, Kawano S, Maruse Y, Matsubara R, Goto Y, Sakamoto T, Hashiguchi Y, Kaneko N, Tanaka H, Kitamura R, Toyoshima T, Jinno A, Moriyama M, Oobu K, Kiyoshima T and Nakamura $\mathrm{S}$ : Increased expression of interleukin- 6 predicts poor response to chemoradiotherapy and unfavorable prognosis in oral squamous cell carcinoma. Oncol Rep 33(5): 2161-2168, 2015. PMID: 25761055. DOI: 10.3892/or.2015.3838

22 Rheinwald JG and Beckett MA: Tumorigenic keratinocyte lines requiring anchorage and fibroblast support cultured from human squamous cell carcinomas. Cancer Res 41(5): 1657-1663, 1981. PMID: 7214336.

23 Abrahao AC, Giudice FS, Sperandio FF and Pinto Junior DD: Effects of celecoxib treatment over the AKT pathway in head and neck squamous cell carcinoma. J Oral Pathol Med 42(10): 793-798, 2013. PMID: 23679684. DOI: 10.1111/jop.12081

24 Niederberger E, Tegeder I, Vetter G, Schmidtko A, Schmidt H, Euchenhofer C, Bräutigam L, Grösch S and Geisslinger G: Celecoxib loses its anti-inflammatory efficacy at high doses through activation of NF-kappaB. FASEB J 15(9): 1622-1624, 2001. PMID: 11427506. DOI: 10.1096/fj.00-0716fje

25 Zhao SZ, McMillen JI, Markenson JA, Dedhiya SD, Zhao WW, Osterhaus JT and Yu SS: Evaluation of the functional status aspects of health-related quality of life of patients with osteoarthritis treated with celecoxib. Pharmacotherapy 19(11): 1269-1278, 1999. PMID: 10555933. 
26 Wirth LJ, Krane JF, Li Y, Othus M, Moran AE, Dorfman DM, Norris CM Jr., Goguen L, Posner MR, Haddad RI and Bertagnolli MM: A pilot surrogate endpoint biomarker study of celecoxib in oral premalignant lesions. Cancer Prev Res (Phila) 1(5): 339-348, 2008. PMID: 19138978. DOI: 10.1158/1940-6207.CAPR-07-0003

27 Patil VM, Noronha V, Joshi A, Muddu VK, Dhumal S, Bhosale B, Arya S, Juvekar S, Banavali S, D'Cruz A, Bhattacharjee A and Prabhash K: A prospective randomized phase II study comparing metronomic chemotherapy with chemotherapy (single agent cisplatin), in patients with metastatic, relapsed or inoperable squamous cell carcinoma of head and neck. Oral Oncol 51(3): 279-286, 2015. PMID: 25578869. DOI: 10.1016/j.oraloncology. 2014.12.002

28 Chang KP, Kao HK, Yen TC, Chang YL, Liang Y, Liu SC, Lee LY, Chang YL, Kang CJ, Chen IH, Liao CT and Yu JS: Overexpression of macrophage inflammatory protein-3alpha in oral cavity squamous cell carcinoma is associated with nodal metastasis. Oral Oncol 47(2): 108-113, 2011. PMID: 21163685. DOI: 10.1016/j.oraloncology.2010.11.012

29 Jung DW, Che ZM, Kim J, Kim K, Kim KY, Williams D and Kim J: Tumor-stromal crosstalk in invasion of oral squamous cell carcinoma: A pivotal role of CCL7. Int J Cancer 127(2): 332-344, 2010. PMID: 19937793. DOI: 10.1002/ijc. 25060

$30 \mathrm{Li} \mathrm{X,} \mathrm{Xu} \mathrm{Q,} \mathrm{Wu} \mathrm{Y,} \mathrm{Li} \mathrm{J,} \mathrm{Tang} \mathrm{D,} \mathrm{Han} \mathrm{L} \mathrm{and} \mathrm{Fan} \mathrm{Q:} \mathrm{A}$ CCL2/ROS autoregulation loop is critical for cancer-associated fibroblasts-enhanced tumor growth of oral squamous cell carcinoma. Carcinogenesis 35(6): 1362-1370, 2014. PMID: 24531940. DOI: $10.1093 /$ carcin/bgu046

31 Silva TA, Ribeiro FL, Oliveira-Neto HH, Watanabe S, Alencar Rde C, Fukada SY, Cunha FQ, Leles CR, Mendonça EF and Batista AC: Dual role of CCL3/CCR1 in oral squamous cell carcinoma: Implications in tumor metastasis and local host defense. Oncol Rep 18(5): 1107-1113, 2007. PMID: 17914560. DOI: $10.3892 /$ or.18.5.1107

32 Chen JJ, Yao PL, Yuan A, Hong TM, Shun CT, Kuo ML, Lee YC and Yang PC: Up-regulation of tumor interleukin-8 expression by infiltrating macrophages: Its correlation with tumor angiogenesis and patient survival in non-small cell lung cancer. Clin Cancer Res 9(2): 729-737, 2003. PMID: 12576442.

33 Chen N, Jiang X, Wang J, Wu T, Cheng B and Xia J: CXCL12CXCR4/CXCR7 axis contributes to cell motilities of oral squamous cell carcinoma. Tumour Biol 37(1): 567-575, 2016. PMID: 26232325. DOI: 10.1007/s13277-015-3803-6

34 Khurram SA, Bingle L, McCabe BM, Farthing PM and Whawell SA: The chemokine receptors CXCR1 and CXCR2 regulate oral cancer cell behaviour. J Oral Pathol Med 43(9): 667-674, 2014. PMID: 24965032. DOI: 10.1111/jop.12191

35 Lang Kuhs KA, Hildesheim A, Trabert B, Kemp TJ, Purdue MP, Wentzensen N, Katki HA, Pinto LA, Loftfield E, Safaeian M, Chaturvedi AK and Shiels MS: Association between regular aspirin use and circulating markers of inflammation: A study within the Prostate, Lung, Colorectal, and Ovarian Cancer Screening Trial. Cancer Epidemiol Biomarkers Prev 24(5): 825-832, 2015. PMID: 25713025. DOI: 10.1158/1055-9965.EPI-14-1363

36 Erstad DJ and Cusack JC Jr.: Targeting the NF-kappaB pathway in cancer therapy. Surg Oncol Clin N Am 22(4): 705-746, 2013. PMID: 24012396. DOI: 10.1016/j.soc.2013.06.011
37 Mocellin S, Rossi CR, Pilati P and Nitti D: Tumor necrosis factor, cancer and anticancer therapy. Cytokine Growth Factor Rev 16(1): 35-53, 2005. PMID: 15733831. DOI: 10.1016/ j.cytogfr.2004.11.001

38 Andersson BA, Lewin F, Lundgren J, Nilsson M, Rutqvist LE, Lofgren $\mathrm{S}$ and Laytragoon-Lewin N: Plasma tumor necrosis factor-alpha and C-reactive protein as biomarker for survival in head and neck squamous cell carcinoma. J Cancer Res Clin Oncol 140(3): 515-519, 2014. PMID: 24481866. DOI: 10.1007/ s00432-014-1592-8

39 Rich AM, Hussaini HM, Parachuru VP and Seymour GJ: Tolllike receptors and cancer, particularly oral squamous cell carcinoma. Front Immunol 5: 464, 2014. PMID: 25309546. DOI: 10.3389/fimmu. 2014.00464

40 Makinen LK, Ahmed A, Hagstrom J, Lehtonen S, Makitie AA, Salo T, Haglund C and Atula T: Toll-like receptors 2, 4, and 9 in primary, metastasized, and recurrent oral tongue squamous cell carcinomas. J Oral Pathol Med 45(5): 338-345, 2016. PMID: 26426362. DOI: 10.1111/jop.12373

41 Zhang H, Zhang J, Nan X, Li X, Qu J, Hong Y, Sun L, Chen Y and Li T: CMTM3 inhibits cell growth and migration and predicts favorable survival in oral squamous cell carcinoma. Tumour Biol 36(10): 7849-7858, 2015. PMID: 25946973. DOI: 10.1007/s13277-015-3504-1

42 Graham GJ: D6 and the atypical chemokine receptor family: Novel regulators of immune and inflammatory processes. Eur $\mathbf{J}$ Immunol 39(2): 342-351, 2009. PMID: 19130487. DOI: $10.1002 /$ eji.200838858

43 Nibbs RJ and Graham GJ: Immune regulation by atypical chemokine receptors. Nat Rev Immunol 13(11): 815-829, 2013. PMID: 24319779.

44 Shi JY, Yang LX, Wang ZC, Wang LY, Zhou J, Wang XY, Shi GM, Ding ZB, Ke AW, Dai Z, Qiu SJ, Tang QQ, Gao Q and Fan $\mathrm{J}$ : $\mathrm{CC}$ chemokine receptor-like 1 functions as a tumour suppressor by impairing CCR7-related chemotaxis in hepatocellular carcinoma. J Pathol 235(4): 546-558, 2015. PMID: 25255875. DOI: 10.1002/path.4450

45 Zhu Z, Sun Z, Wang Z, Guo P, Zheng X and Xu H: Prognostic impact of atypical chemokine receptor expression in patients with gastric cancer. J Surg Res 183(1): 177-183, 2013. PMID: 23462454. DOI: $10.1016 / j$.jss.2013.01.023

46 Green CJ, Charles RS, Edwards BF and Johnson PH: Identification and characterization of PF4varl, a human gene variant of platelet factor 4. Mol Cell Biol 9(4): 1445-1451, 1989. PMID: 2725510.

47 Jian J, Pang Y, Yan HH, Min Y, Achyut BR, Hollander MC, Lin $\mathrm{PC}$, Liang $\mathrm{X}$ and Yang L: Platelet factor 4 is produced by subsets of myeloid cells in premetastatic lung and inhibits tumor metastasis. Oncotarget 8(17): 27725-27739, 2017. PMID: 2722 3426. DOI: 10.18632 /oncotarget.9486

Received February 11, 2019

Revised March 31, 2019

Accepted April 3, 2019 